\title{
SEM/EDX, XPS, CORROSION AND SURFACE ROUGHNESS CHARACTERIZATION OF AISI 316L SS AFTER ELECTROCHEMICAL TREATMENT IN CONCENTRATED HNO ${ }_{3}$
}

\author{
Krzysztof Rokosz, Tadeusz, Hryniewicz, Steinar Raaen, Jan Valiček
}

Original scientific paper

In the paper there is described the AISI 316L stainless steel surface obtained after electrochemical treatment in concentrated $\mathrm{HNO}_{3}$. It was characterized by roughness parameters, corrosion protection behaviour and chemical composition of the surface layer. Generally used 2D and 3D roughness parameters describing the surface after the electrochemical treatment are the following: $R a=0.737 \mu \mathrm{m}$ and $S a=1,13 \mu \mathrm{m}$ as well as $R q=0,895 \mu \mathrm{m}$ and Sq $=1,37$ $\mu \mathrm{m}$. In case of corrosion studies the passive current density was equal to $2,3 \times 10^{-2} \mu \mathrm{A} / \mathrm{cm}^{2}$, pitting potential was equal to $E_{\text {pit }}=1140 \mathrm{mV}$ vs. SCE and repassivation potential was $79 \mathrm{mV}$ vs. SCE. In the surface layer there were detected compounds of iron, chromium, molybdenum, cobalt, manganese, as well as calcium (contamination). The high resolution XPS spectra/results data have shown that most of detected iron compounds can be described as $\mathrm{Fe}_{2} \mathrm{O}_{3} / \mathrm{FeOOH}$ and chromium compounds as $\mathrm{Cr}_{2} \mathrm{O}_{3} / \mathrm{CrOOH}$. The molybdenum detected in the surface layer was mainly in valency states six $(65$ at $\%)$ and five $(17$ at $\%)$

Keywords: AISI 316L SS; corrosion characteristics; electrochemical treatment; $\mathrm{HNO}_{3}$; surface roughness; XPS

\section{SEM/EDX, XPS, korozija i karakterizacija hrapavosti površine AISI 316L SS nakon elektrokemijske obrade u koncentriranoj $\mathrm{HNO}_{3}$}

Izvorni znanstveni članak

U radu se opisuje površina nehrđajućeg čelika AISI 316L poslije elektrokemijske obrade u koncentriranoj $\mathrm{HNO}_{3}$. Obilježena je prametrima hrapavosti, ponašanjem kod zaštite od korozije i kemijskim sastavom površinskog sloja. Uobičajeno korišteni 2D i 3D parametri hrapavosti koji opisuju površinu nakon elektrokemijske obrade su sljedeći: $R a=0,737 \mu \mathrm{m}$ i $S a=1,13 \mu \mathrm{m}$ kao i $R q=0,895 \mu \mathrm{m}$ i $S q=1,37 \mu \mathrm{m}$. Kod proučavanja korozije pasivna gustoća struje bila je $2,3 \times 10^{-2} \mu \mathrm{A} / \mathrm{cm}^{2}$, potencijal točkaste korozije $E_{\text {pit }}=1140 \mathrm{mV}$ vs. SCE i mogućnost ponovnog pasiviziranja bio je $79 \mathrm{mV}$ vs. SCE. U površinskom su sloju otkriveni spojevi željeza, kroma, molibdena, kobalta, mangana, kao i kalcija (zagađenost). Rezultati visoke rezolucije XPC spektra pokazali su da se većina pronađenih željeznih spojeva može opisati kao $\mathrm{Fe}_{2} \mathrm{O}_{3} / \mathrm{FeOOH}$, a spojevi kroma kao $\mathrm{Cr}_{2} \mathrm{O}_{3} / \mathrm{CrOOH}$. $\mathrm{Molibden}$ otkriven $\mathrm{u}$ površinskom sloju bio je uglavnom sa strukturom valencija šest (65 at \%) i pet (17 at \%).

Ključne riječi: AISI 316L SS; elektrokemijska obrada; $\mathrm{HNO}_{3}$; XPS; značajke korozije; hrapavost površine

\section{Introduction}

Stainless steels are commonly treated by electropolishing considered as a standard electrochemical process/treatment $[1 \div 6]$. The process is generally used in industry for finishing operations and is often carried out in the mixture of two acids, $\mathrm{H}_{2} \mathrm{SO}_{4}$ and $\mathrm{H}_{3} \mathrm{PO}_{4}[7 \div 10]$. After this process a treated part reveals smooth and bright surface with good corrosion resistance and improved mechanical properties $[10 \div 16]$. It is of special importance when using that stainless steel as a biomaterial. Concerning improved corrosion resistance $[12 \div 18]$, the steel parts may be chemically treated in concentrated nitric acid and that process is described in the literature $[19 \div 21]$. On the other hand, there are no study results available on electrochemical treatment of stainless steels in concentrated nitrogen acid.

The use of an oxidizing acid, such as nitric acid, for passivation has two purposes. First of all, the acid dissolves any surface inclusions in the steel. Secondly, it assures a uniform, clean surface those results in the consistent formation of the passive chromium oxide film (and molybdenum film) [2]. The passivation process enhances the chromium fraction in the passive film, as established before $[4,12,16]$. The main mechanism for this process is selective dissolution of predominantly iron $[3,4]$. In addition to the chemical process with a standard immersion in nitric acid solution the electrochemical treatment is proposed.

The aim of the study is to perform electropolishing of AISI 316L stainless steel in $\mathrm{HNO}_{3}$ and investigate the surface properties after that operation. Specifically, the study of the corrosion behaviour of that steel in a typical Ringer's solution $[7,13,16]$ was investigated. Thorough characterization of such obtained 316L steel surface may be of a great practical value.

\section{Method \\ 2.1 Material}

For the study there were used samples of the AISI 316L austenitic chromium-nickel-molybdenum stainless steel. The addition of molybdenum to the stainless steel increases corrosion resistance and mechanical properties. Typically that sort of steel is very often used in food, pharmaceutical, marine, architecture applications, as well as applied for biomaterial. The bulk composition of the steel, by standard, and as-measured, is shown in Tab. 1 . Second column of Tab. 1 presents composition provided by the manufacturer [15].

Ten samples of AISI 316L stainless steel as received of dimensions $60 \times 30 \times 1(\mathrm{~mm})$ were prepared for the studies. They were treated by electrochemical treatment in concentrated $\mathrm{HNO}_{3}$ under defined conditions, with the current density used $i=65 \pm 5 \mathrm{~A} / \mathrm{dm}^{2}$. The electrochemical polishing process was carried out for 3 minutes time in the electrolyte of temperature of $65{ }^{\circ} \mathrm{C}$, with the temperature control of $\pm 10{ }^{\circ} \mathrm{C}$. The electrolytic cell was made of glass, containing up to $500 \mathrm{~cm}^{3}$ of electrolyte. Afterwards the samples were rinsed in distilled water for about 2 minutes and dried in air for about 3 minutes. 
Table 1 Chemical composition of AISI 316L stainless steel

\begin{tabular}{|l|c|c|}
\hline \multicolumn{1}{|c|}{ Element } & $\begin{array}{c}\text { Typical } \\
\text { composition, } \mathrm{wt} \%\end{array}$ & $\begin{array}{c}\text { Content } \\
\text { as measured, } \mathrm{wt} \%\end{array}$ \\
\hline Chromium & $16 \div 18$ & 16,92 \\
\hline Nickel & $10 \div 14$ & 10,38 \\
\hline Manganese & $2(\max )$ & 1,30 \\
\hline Molybdenum & $2 \div 3$ & 2,01 \\
\hline Nitrogen & $0,1(\max )$ & 0,04 \\
\hline Carbon & $0,03(\max )$ & 0,02 \\
\hline Silicon & $0,75(\max )$ & 0,39 \\
\hline Phosphorus & $0,045(\max )$ & 0,32 \\
\hline Sulphur & $0,03(\max )$ & 0,01 \\
\hline Copper & - & 0,28 \\
\hline Vanadium & - & 0,09 \\
\hline Cobalt & - & 0,19 \\
\hline Aluminium & - & 0,01 \\
\hline Iron & Balance & 68,04 \\
\hline
\end{tabular}

The surface roughness studies were carried by interferometric method with Taylor-Hobson Precision Talysurf CCI 6000 (Coherent Correlation Interferometry). The SEM/EDX measurements were performed on ASPEX EXPLORER ${ }^{\mathrm{TM}}$ apparatus. The XPS experiments were carried out in an ultra-high-vacuum system with a base pressure of about $10^{-8} \mathrm{~Pa}$. The XPS measurements, with the angle of $90^{\circ}$, were performed using a SES2002 electron energy analyzer with a monochromatized Al K $\alpha$ ( $h v=1486,6 \mathrm{eV})$ X-ray source (Gammadata-Scienta). A total resolution of about $0,6 \mathrm{eV}$ was obtained for the presented spectra. In view of optimizing the signal-tonoise ratio, one XPS measurement cycle covered 100 sweeps. For the XPS analyses the CasaXPS 2.3.14 software was used [22 $\div 24]$. The XPS spectra were analysed by using Shirley background and GL(30), LA $(1,2 ; 4,8 ; 3)$, LA $(1,3 ; 4 ; 5)$ line shapes $[25 \div 29]$.

Corrosion studies after electrochemical treatment were carried out in a typical Ringer's physiological fluid, at $25{ }^{\circ} \mathrm{C}$. The electrochemical system used for the corrosion measurements consisted of a potentiostat ATLAS 98 with the software IMP98, a platinum counter electrode Ept-101, and a saturated calomel reference electrode EK-101P. The corrosion measurements data were recorded every $5 \mathrm{mV}$ with the rate of $0,1 \mathrm{mV} / \mathrm{s}$. In the case of the potentiodynamic measurements the specimens were immersed in the same solution for 1 hour prior to the measurement in order to stabilize the surface at the conditions of open circuit potential.

\section{Study results}

In Fig. 1 there are shown the SEM photo and EDX spectrum of surface after electrochemical treatment in concentrated $\mathrm{HNO}_{3}$. The structure of the treated steel surface is revealed and, on the basis of the EDX results one may easily notice there is a possibility to determine the chemical composition of the obtained surface. In that case there were detected the biggest signals from iron, chromium and nickel.

In order to investigate in detail the chemical composition of surface layer formed after electrochemical treatment in concentrated $\mathrm{HNO}_{3}$, the XPS spectroscopy as survey scan (Fig. 2) was used. On the basis of that method, in surface layer there were more chemical elements than only iron, chromium and nickel detected, with such additional elements like oxygen, molybdenum, cobalt, manganese, as well as calcium as contamination. The survey of XPS study has shown more information about the surface layer than that from EDX, but still not enough. In that situation there were used the high resolution XPS measurements for iron, chromium and molybdenum; they are presented in Figs. $3 \div 5$ and in Tabs. $2 \div 4$
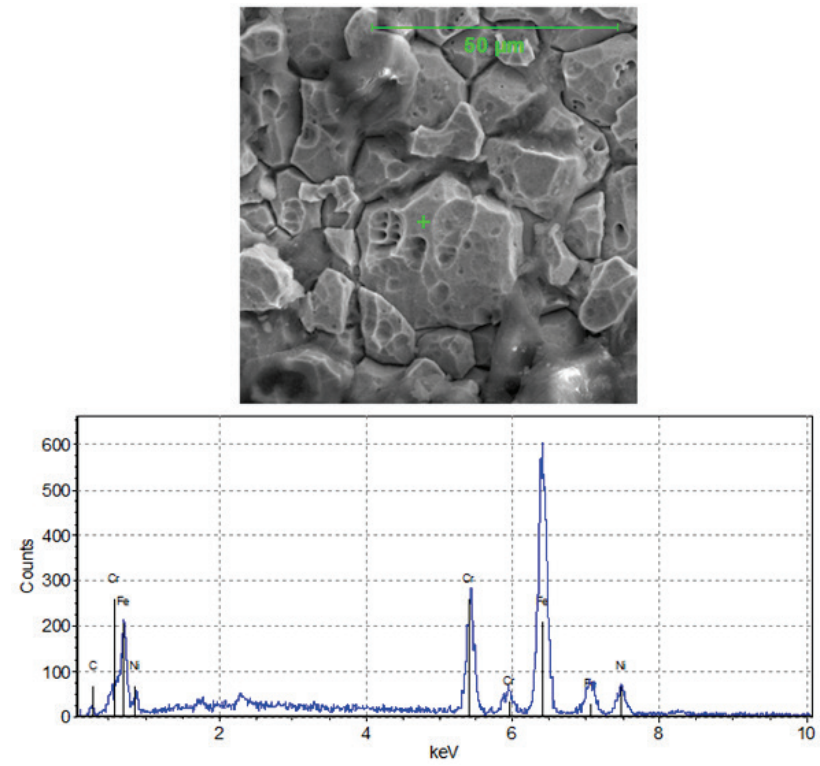

Figure $1 \mathrm{SEM} / \mathrm{EDX}$ results of AISI 316L SS after electrochemical treatment in concentrated $\mathrm{HNO}_{3}$

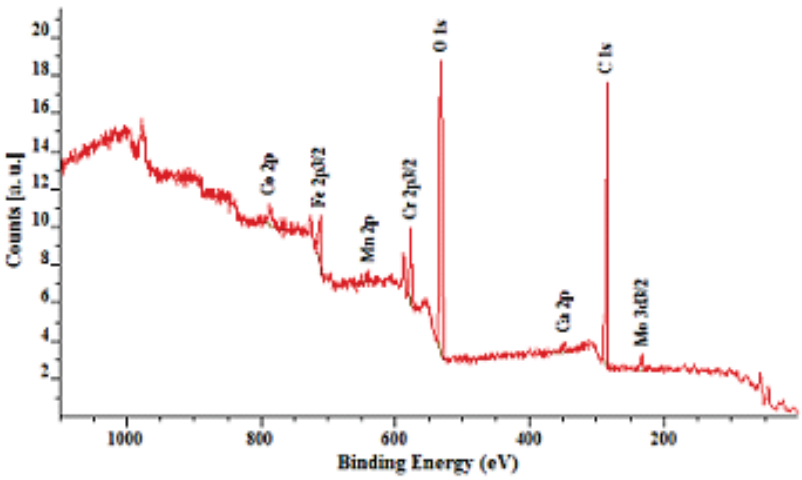

Figure 2 XPS survey results of AISI 316L SS after electrochemical treatment in concentrated $\mathrm{HNO}_{3}$

The Fe $2 p$ spectrum was fitted by two peaks: one line for iron metal Fe-M and the second one for a compound part Fe-X. Shape lines for iron spectrum fitting from GL(30) (metal and compounds spectrum part) and LA(1.2,4.8,3) (metal part) were selected. On the basis of results shown in Fig. 3 and Tab. 2 it is visible that the atomic percent of iron metal is in the range of $4,3 \div 4,4$ at $\%$ and percent of iron compounds amounts for $95,6 \div$ 95,7 at $\%$.

Fitting by two peaks is not the best method, but with well-chosen line shapes it should provide essential information about the predominance of oxides, hydroxides as well as phosphates and sulphates of iron. Therefore two peaks analysis for binding energy 711,5 eV was performed. In the presented data the most probable chemical iron compound appears to be a mixture of $\mathrm{Fe}_{2} \mathrm{O}_{3} / \mathrm{FeOOH}$. 

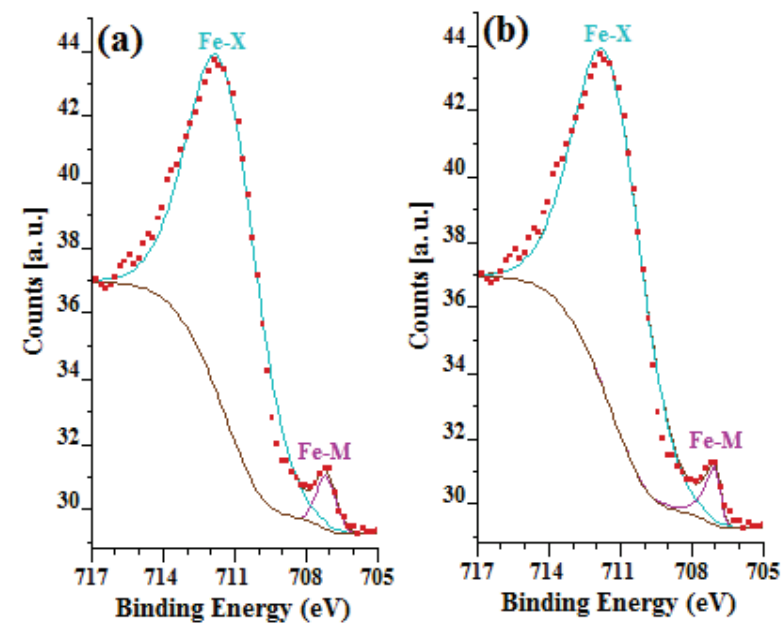

Figure 3 XPS high resolution of $\mathrm{Fe} 2 \mathrm{p} 3 / 2$ spectra fitting by GL(30) shape lines (a) and LA(1,2; 4,8; 3 ) plus GL(30) (b); RSTD (Residual Standard Deviation) of two peaks analysis 0,066 , analysis by $\mathrm{LA}(1,2$ $4,8 ; 3)$ plus GL(30) shape lines; RSTD of two peaks analysis 0,064 , analysis by GL(30) shape lines
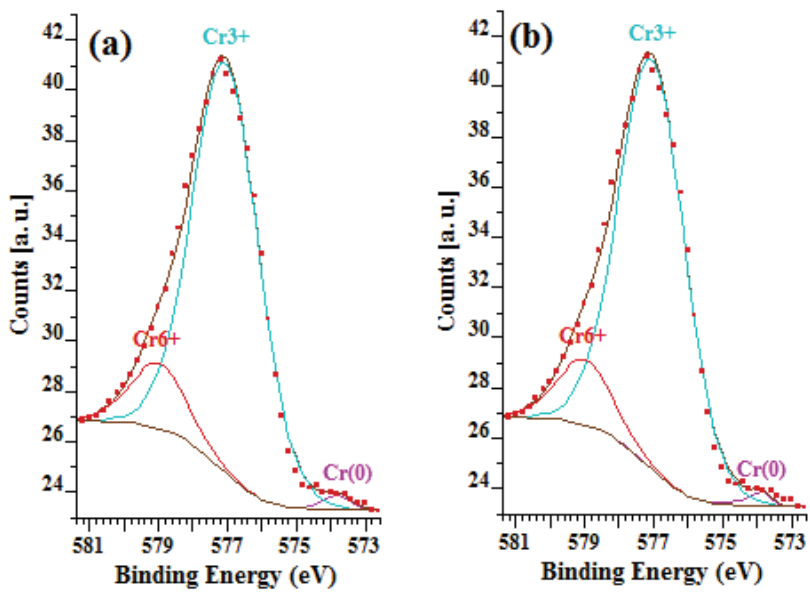

Figure 4 XPS high resolution of $\mathrm{Cr} 2 \mathrm{p}_{3 / 2}$ spectra fitting by GL(30) shape lines (a) and LA( 1,$3 ; 4 ; 5)$ plus GL(30) (b); RSTD (Residual Standard Deviation) of analyses by $\mathrm{LA}(1,3 ; 4 ; 5)$ plus GL(30) shape lines is 0,061 ; RSTD of analysis by GL(30) shape lines is also 0,061

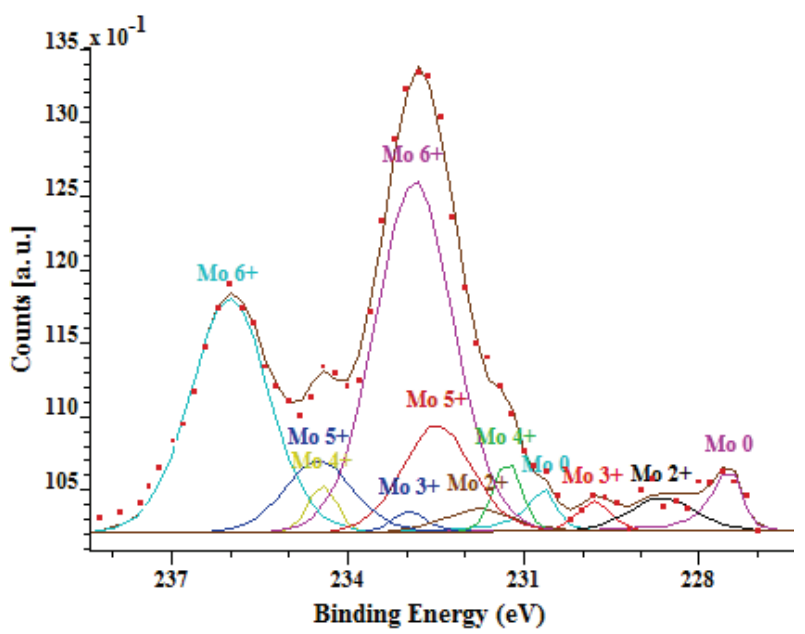

Figure 5 XPS high resolution results of AISI 316L SS after electrochemical treatment in concentrated $\mathrm{HNO}_{3}$, RSTD=0,034; (RSTD: Residual Standard Deviation)

Table 2 Analyses of Fe 2 p spectrum by GL(30) and LA(1,2; 4,8; 3$)$ line

\begin{tabular}{|c|c|c|c|c|}
\hline BE / eV & 707,1 & 711,5 & 707,0 & 711,5 \\
\hline FWHM & 0,970638 & 3,38146 & 0,464694 & 3,36522 \\
\hline Line shape & GL(30) & GL(30) & LA $(1,2 ; 4,8 ; 3)$ & GL(30) \\
\hline AREA & 1,7 & 38,5 & 1,8 & 38,4 \\
\hline Fe 2 $\mathrm{p}_{3 / 2} /$ at $\%$ & 4,3 & 95,7 & 4,4 & 95,6 \\
\hline $\begin{array}{c}\text { Iron } \\
\text { compounds }\end{array}$ & Fe-M & Fe-X & Fe-M & Fe-X \\
\hline
\end{tabular}

In Fig. 5 and Tab. 4 there are shown the XPS results of molybdenum Mo 3d spectrum. The molybdenum metal was fitted by $\operatorname{LA}(1,1 ; 2,3 ; 2)$ and molybdenum compounds by GL(30). It was detected that in surface layer there were mainly molybdenum compounds in valency states six $(65 \mathrm{at} \%)$ and five $(17,4 \mathrm{at} \%)$. The other Mo valency states (2, 3 and 4) as well as metal part of molybdenum spectrum were in the range from 2,4 at $\%$ to 5,4 at $\%$.

Table 3 Analyses of $\mathrm{Cr} 2 \mathrm{p}$ spectrum by GL( 30$)$ and $\mathrm{LA}(1.3,4,5)$ line shapes

\begin{tabular}{|c|c|c|c|c|c|c|}
\hline BE / eV & 573,8 & 577,0 & 579,0 & 573,8 & 577,0 & 579,0 \\
\hline FWHM & 0,479 & 2,257 & 1,921 & 0,480 & 2,257 & 1,921 \\
\hline Line Shape & $\mathrm{GL}(30)$ & $\mathrm{GL}(30)$ & $\mathrm{GL}(30)$ & $\mathrm{LA}(1,3 ; 4,5)$ & $\mathrm{GL}(30)$ & $\mathrm{GL}(30)$ \\
\hline AREA & 0,5 & 40,1 & 5,4 & 0,5 & 40,1 & 5,4 \\
\hline $\mathrm{Cr} 2 \mathrm{p}_{3 / 2} /$ at $\%$ & 1,0 & 87,3 & 11,7 & 1,0 & 87,3 & 11,7 \\
\hline Oxidation stage & $\mathrm{Cr}$ & $\mathrm{Cr}^{3+}$ & $\mathrm{Cr}^{6+}$ & $\mathrm{Cr}^{0}$ & $\mathrm{Cr}^{3+}$ & $\mathrm{Cr}^{6+}$ \\
\hline Chromium Compounds & $\mathrm{Cr}(0)$ & $\mathrm{Cr}_{2} \mathrm{O}_{3} / \mathrm{CrOOH}$ & $\left(\mathrm{CrO}_{4}\right)^{2}$ & $\mathrm{Cr}(0)$ & $\mathrm{Cr}_{2} \mathrm{O}_{3} / \mathrm{CrOOH}^{2}$ & $\left(\mathrm{CrO}_{4}\right)^{2}$ \\
\hline
\end{tabular}

Table 4 Analysis of Mo 3D spectrum

\begin{tabular}{|c|c|c|c|c|c|c|c|}
\hline \multirow{5}{*}{ 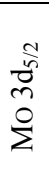 } & $\mathrm{BE} / \mathrm{eV}$ & 227,5 & 228,6 & 229,8 & 231,3 & 232,5 & 232,9 \\
\hline & FWHM & 0,45132 & 1,2986 & 0,68264 & 0,56245 & 1,36908 & 1,54734 \\
\hline & Line Shape & $\mathrm{LA}(1,1 ; 2,3 ; 2)$ & GL(30) & GL(30) & GL(30) & GL(30) & GL(30) \\
\hline & AREA & 0,3 & 0,3 & 0,1 & 0,3 & 1,1 & 4,0 \\
\hline & at $\%$ & 3,24 & 3,08 & 1,44 & 2,8 & 10,46 & 38,98 \\
\hline \multirow{5}{*}{$\begin{array}{l}\frac{N}{D} \\
\stackrel{n}{n} \\
\stackrel{2}{\Sigma}\end{array}$} & $\mathrm{BE} / \mathrm{eV}$ & 230,6 & 231,8 & 232,9 & 234,4 & 234,5 & 236,0 \\
\hline & FWHM & 0,45132 & 1,2986 & 0,68264 & 0,56245 & 1,36908 & 1,54734 \\
\hline & Line Shape & $\mathrm{LA}(1,1 ; 2,3 ; 2)$ & GL(30) & GL(30) & GL(30) & GL(30) & GL(30) \\
\hline & AREA & 0,2 & 0,2 & 0,1 & 0,2 & 0,7 & 2,7 \\
\hline & at $\%$ & 2,16 & 2,05 & 0,96 & 1,87 & 6,97 & 25,99 \\
\hline & Total $/$ at $\%$ & 5,4 & 5,1 & 2,4 & 4,7 & 17,4 & 65,0 \\
\hline & & $\mathrm{Mo}^{0}$ & $\mathrm{Mo}^{2+}$ & $\mathrm{Mo}^{3+}$ & $\mathrm{Mo}^{4+}$ & $\mathrm{Mo}^{5+}$ & $\mathrm{Mo}^{6+}$ \\
\hline
\end{tabular}


Table $52 \mathrm{D}$ roughness parameters according to ISO 4287

\begin{tabular}{|l|c|c|l|}
\hline$R a$ & 0,737 & $\mu \mathrm{m}$ & $R a:$ Arithmetic mean deviation of the roughness profile \\
\hline$R q$ & 0,895 & $\mu \mathrm{m}$ & $R q:$ Root-Mean-Square (RMS) Deviation of the roughness profile \\
\hline$R p$ & 1,72 & $\mu \mathrm{m}$ & $R p:$ Maximum peak height of the roughness profile \\
\hline$R v$ & 1,77 & $\mu \mathrm{m}$ & $R v:$ Maximum Valley Depth of the roughness profile \\
\hline$R t$ & 5,95 & $\mu \mathrm{m}$ & $R t:$ Total height of roughness profile \\
\hline$R z$ & 3,49 & $\mu \mathrm{m}$ & $R z:$ Maximum height of roughness profile \\
\hline$R c$ & 2,26 & $\mu \mathrm{m}$ & $R c:$ Mean height of the roughness profile elements \\
\hline$R s k$ & 0,048 & - & $R s k:$ Skewness of the roughness profile \\
\hline$R k u$ & 2,46 & - & $R k u:$ Kurtosis of the roughness profile \\
\hline
\end{tabular}

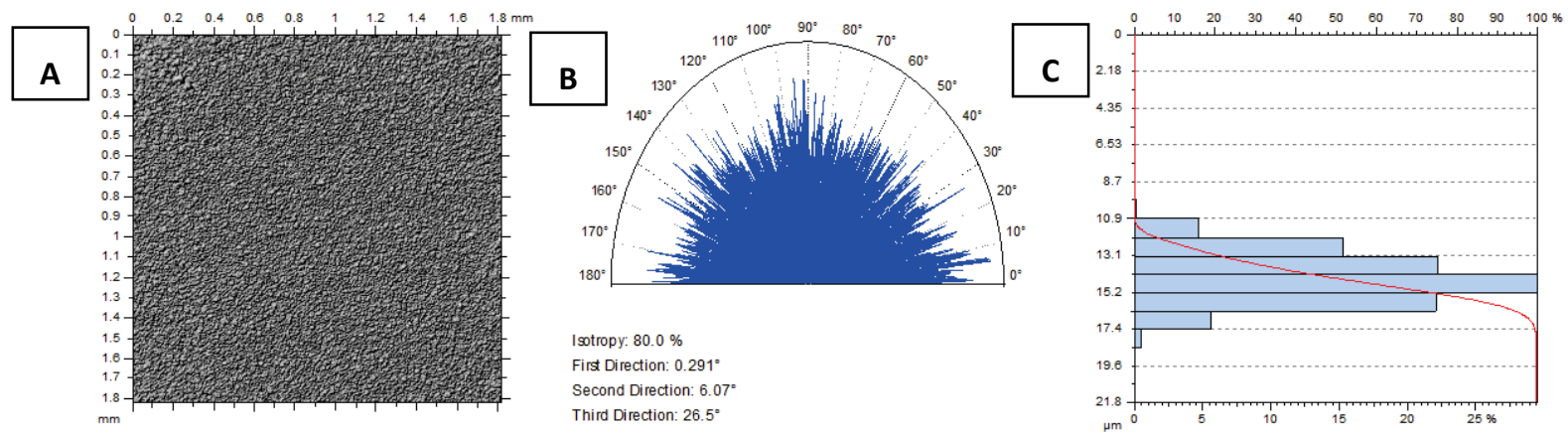

Figure 6 Surface characteristics in 3D: surface simulation (A), texture direction (B), and Abbott-Firestone curve (C)

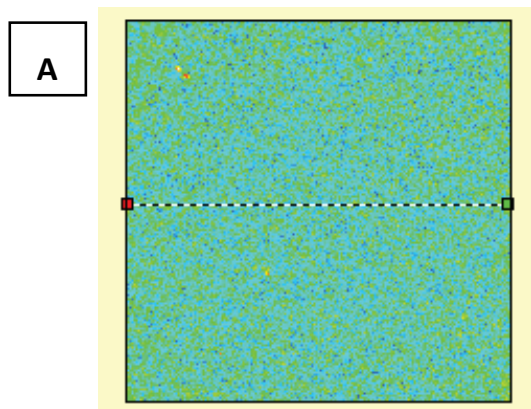

Extracted profile

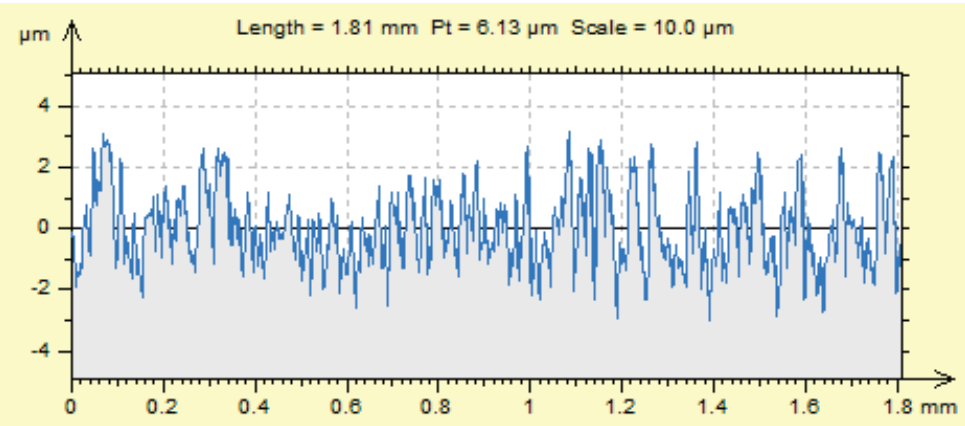

B $\quad \mu m \uparrow$

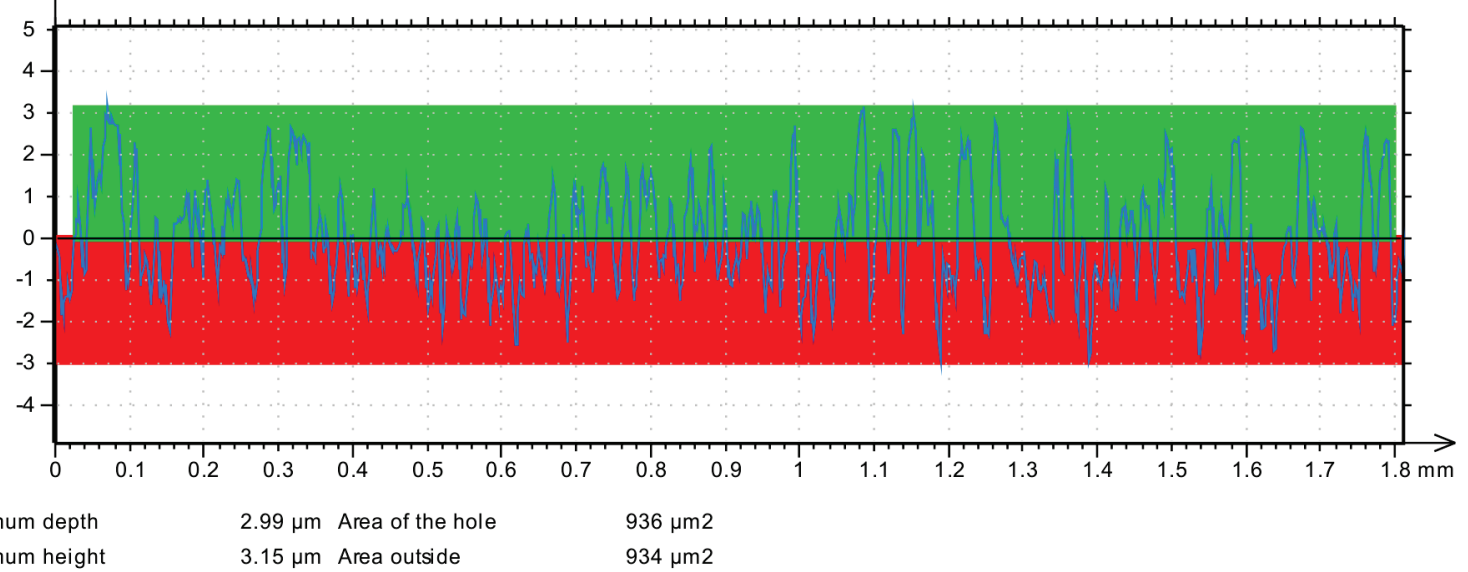

Figure 7 Surface characteristics in 2D: surface simulation (A), roughness profile (B)

Table 6 Height 3D roughness parameters according to ISO 25178

\begin{tabular}{|c|c|c|l|}
\hline$S a$ & 1,13 & $\mu \mathrm{m}$ & $S a:$ Arithmetic mean height \\
\hline$S q$ & 1,37 & $\mu \mathrm{m}$ & $S q$ : Root mean square height \\
\hline$S p$ & 14,3 & $\mu \mathrm{m}$ & $S p:$ Maximum peak height \\
\hline$S v$ & 7,44 & $\mu \mathrm{m}$ & $S v:$ Maximum pit height \\
\hline$S z$ & 21,8 & $\mu \mathrm{m}$ & $S z:$ Maximum height \\
\hline$S s k$ & 0,253 & - & $S s k:$ Skewness \\
\hline$S k u$ & 3,28 & - & $S k u:$ Kurtosis \\
\hline$S a$ & 1,13 & $\mu \mathrm{m}$ & $S a:$ Arithmetic mean height \\
\hline
\end{tabular}




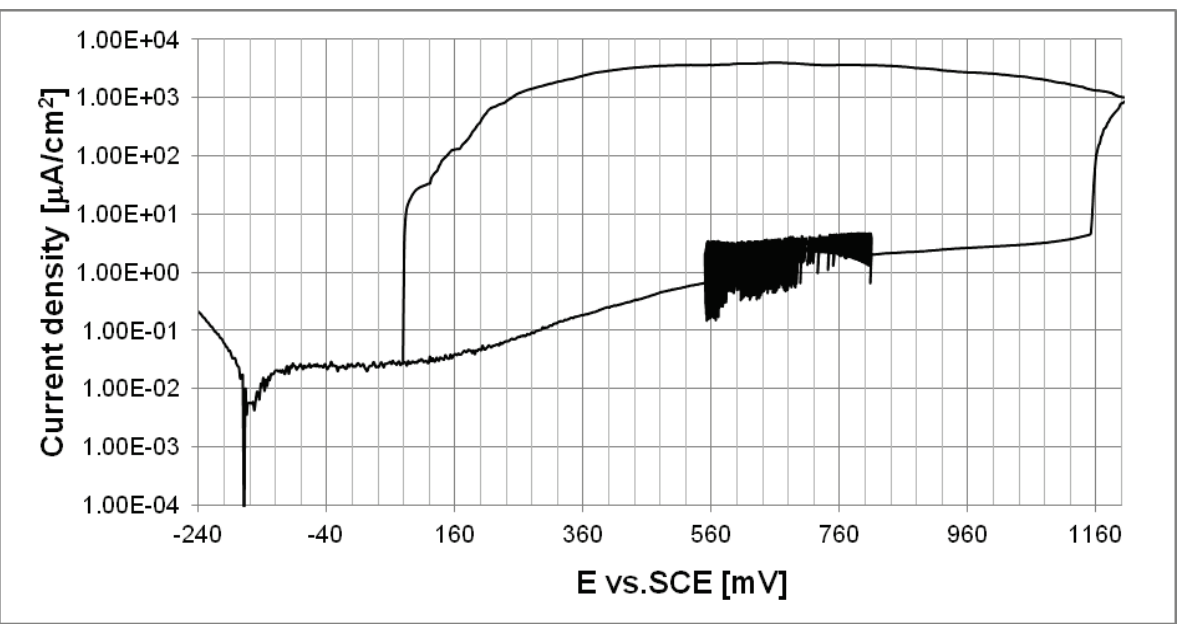

Figure 8 Polarization curve of AISI 316L SS after electrochemical treatment in concentrated $\mathrm{HNO}_{3}$
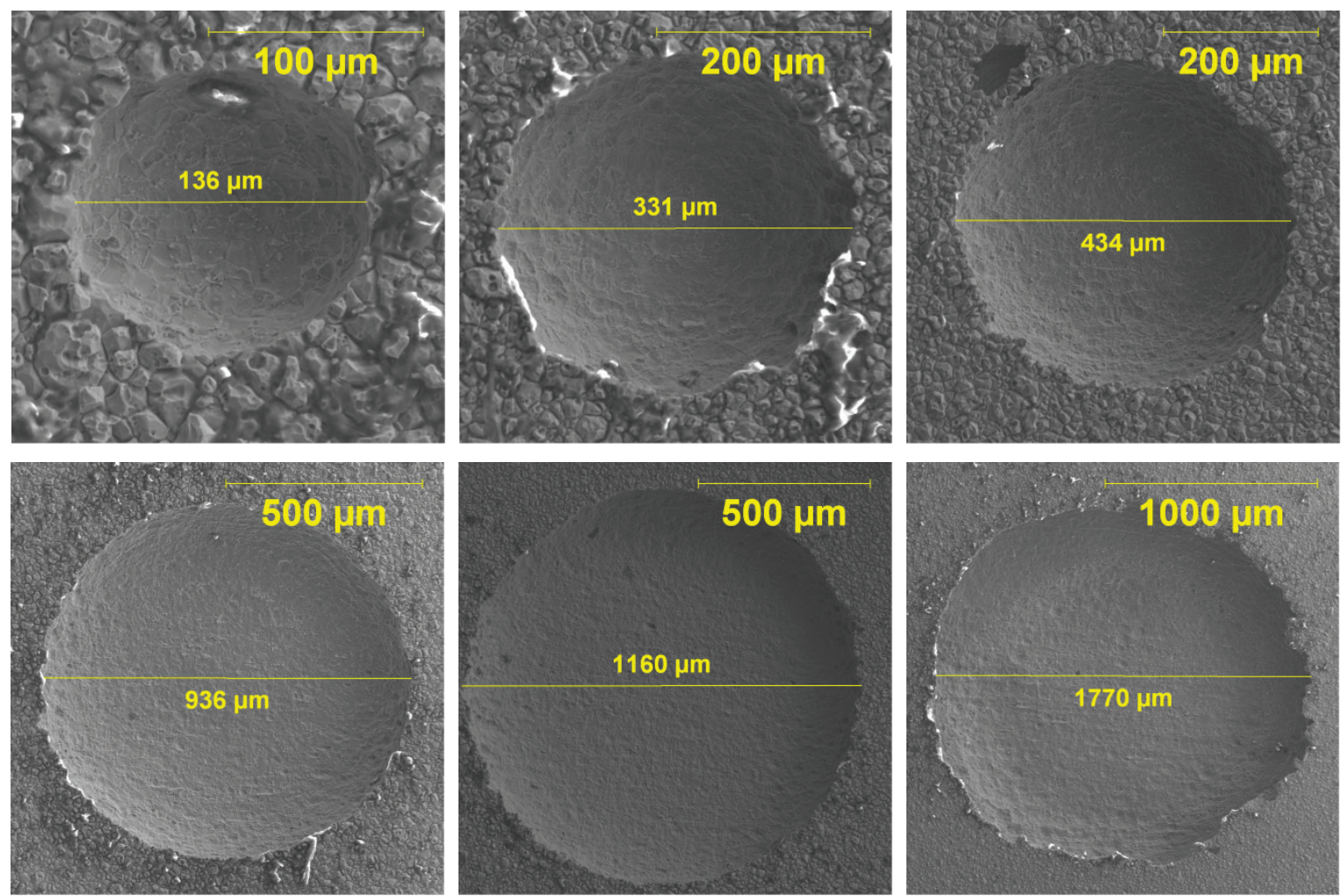

Figure 9 Pit development in the Ringer's solution (example of results)

In Figs. 5 and 6 there are shown the results of surface topography analysis i.e. $3 \mathrm{D}$ and $2 \mathrm{D}$ surface simulations, texture direction, Abbott-Firestone curve, roughness profile as well as $2 \mathrm{D}$ and $3 \mathrm{D}$ roughness parameters with Gaussian filter and cut-off equal to $0,08 \mathrm{~mm}$ (Tabs. 5 and $6)$. There is not visible one texture direction what can be observed on the surfaces after mechanical polishing. Obtained surface is uniform, characterized by $2 \mathrm{D}$ and $3 \mathrm{D}$ roughness parameters: $R a=0,737 \mu \mathrm{m}, R q=0,895 \mu \mathrm{m}$ and $S a=1,13 \mu \mathrm{m}, S q=1,37 \mu \mathrm{m}$.

In Fig. 8 there is shown an exemplary curve of potentiodynamic corrosion measurements of surface after electrochemical treatment in concentrated $\mathrm{HNO}_{3}$. The average of passive current density equals $2,3 \times 10^{-2}$ $\mu \mathrm{A} / \mathrm{cm}^{2}$. The pitting corrosion resistance corresponding to pitting potential (1140 $\mathrm{mV}$ vs. SCE) is higher than that after a standard electrochemical polishing $\left(E_{\text {pit }}=600 \mathrm{mV}\right.$ vs. SCE), and re-passivation potential equals $79 \mathrm{mV}$ vs. SCE. The dark dense area between $560 \mathrm{mV}$ and $800 \mathrm{mV}$ in Fig. 8 indicates the unstable pits, which undergo to repassivation.

In Fig. 9 there are given SEM photos of pit development in Ringer's solution with the pits of increasing diameters. They were taken on ASPEX EXPLORER $^{\mathrm{TM}}$ device from a typical sample after electrochemical corrosion studies.

\section{Discussion}

In presented paper, there is shown the compact surface film characterization of AISI $316 \mathrm{~L}$ austenitic stainless steel after electropassivation in $\mathrm{HNO}_{3}$. It is a novel approach to the subject of surface finishing. The most interesting findings in the article are the analysis of chromium compounds especially of the sixth level oxidation compounds as well as molybdenum states of oxidation on the background of iron compounds analysis. To illustrate the changes after the treatment, the SEM 
photos of the sample after proposed electro-passivation with EDX surface analysis (Fig. 1) plus additional information of 3D surface roughness measurements (Figs. 6 and 7, and Tabs. 5 and 6) are given. In order to characterize the corrosion resistance, there were shown the polarization characteristics (Fig. 8), which comprehensively describe the properties of the surface layer formed. The authors' previous results [7, 13] obtained on 316L SS after a standard electropolishing in the Ringer's solution indicate the level of pitting corrosion resistance of about $600 \mathrm{mV}$ versus SCE. In their analysis of AISI 316L surface after electropolishing and passivation in $\mathrm{HNO}_{3}$ the Henkels [30] show that the difference between the pitting potentials of only electropolished and electropolished plus passivated $316 \mathrm{~L}$ SS sample was about $100 \mathrm{mV}$. Other researchers find [21] that nitric acid passivation can increase the pitting potential of AISI 316 stainless steel. Following this reasoning the steel surface after passivation in $\mathrm{HNO}_{3}$ should be about maximum in the range of $(700 \div 800)$ $\mathrm{mV}$ vs. SCE. In comparison, the data in this paper show that the pitting potential is equal to $1160 \mathrm{mV}$ only after electro-passivation treatment in $\mathrm{HNO}_{3}$ (mechanical/ abrasive polishing was used as the pre-treatment only). On the basis of literature data obtained and current knowledge in the field of surface finishing, our results should be considered as much better and the method innovative.

\section{Conclusion}

In the article there was described the surface obtained after electrochemical treatment in concentrated $\mathrm{HNO}_{3}$. It was characterized due to roughness, corrosion protection and chemical composition of the surface layer. The obtained roughness was equal to $S a=1,13 \mu \mathrm{m}(\mathrm{Ra}=$ $0,737 \mu \mathrm{m}), S q=1,37 \mu \mathrm{m}(R q=0,895 \mu \mathrm{m})$. The corrosion resistance in the Ringer's solution was described by a passive current density $\left(i_{\text {pass }}=2,3 \times 10^{-2} \mu \mathrm{A} / \mathrm{cm}^{2}\right)$, pitting corrosion potential $\left(E_{\mathrm{pit}}=1140 \mathrm{mV}\right.$ vs. SCE) and repassivation potential $\left(E_{\text {repass }}=79 \mathrm{mV}\right.$ vs. SCE $)$. The XPS spectroscopy was used to find the composition of the surface layer after the treatment performed. On the basis of obtained data, there were detected the following chemical elements: iron, chromium, molybdenum, cobalt, manganese, as well as calcium (contamination). The high resolution XPS spectra have shown that iron compounds can be described as $\mathrm{Fe}_{2} \mathrm{O}_{3} / \mathrm{FeOOH}$ and chromium compounds as $\mathrm{Cr}_{2} \mathrm{O}_{3} / \mathrm{CrOOH}$. Concerning $\mathrm{Mo}$ as the alloying element of AISI 316L SS, it was detected that in surface layer there was mainly molybdenum in valency states $6(65 \mathrm{at} \%)$ and $5(17,4 \mathrm{at} \%)$. The Mo valency states such as zero, two, three and four were in the amount range from 2,4 at $\%$ to 5,4 at $\%$.

\section{Acknowledgment}

Professor Dr Gregor Mori of the Institute of Schadensanalytik, Montanuniversität Leoben, Austria, is greatly acknowledged for getting chemical analysis of the AISI 316L austenitic stainless steel samples. Professor Wojciech Kacalak of the Koszalin University of Technology is acknowledged for making available the instruments of Taylor-Hobson Precision Talysurf CCI 6000. Dr Robert Tomkowski, a specialist of the Laboratory for Micro- and Nanoengineering, is thankful for the surface analysis carried out using the Talysurf CCI 6000 .

\section{References}

[1] Davidson, J. A.; Kovacs, P. Passivation method and passivated implant, Patent EP 0520721 A2 (1992)

[2] Maller, R. R. Passivation of Stainless Steel. // Trends in Food Science and Technology. 9, (1998), pp. 28-32.

[3] Baron, A; Simka, W; Nawrat, G.; Szewieczek, D. Electropolishing and chemical passivation of austenitic steel // J. Achievements in Materials and Manufacturing Engineering. 31, 2(2008), pp. 197-202.

[4] Parsapour, A.; Fathi, M. H.; Salehi, M.; Saatchi, A.; Mehdikhani, M. The Effect of Surface Treatment on Corrosion Behavior of Surgical 316L Stainless Steel Implant. // Intern. J. ISSI. 4, 1-2(2007), pp. 34-38.

[5] http://www.electrohio.com/Finishing/Passivation/Passivatio n.htm

[6] McCafferty, E. Introduction to Corrosion Science. Springer New York, Dordrecht, Heidelberg, London, DOI: 10.1007/978-1-4419-0455-3 (2010).

[7] Rokosz K. Polerowanie elektrochemiczne stali w polu magnetycznym (Electrochemical polishing of steels in the magnetic field). Monograph $\mathrm{Nr} 219$, Publisher: Koszalin University of Technology, Koszalin 2012, ISSN 02397129, (211 pages), (in Polish).

[8] Hryniewicz, T.; Rokicki, R.; Rokosz, K. Magnetoelectropolishing for metal surface modification. // Trans. of the Institute of Metal Finishing. 85, 6(2007), pp. 325-332.

[9] Hryniewicz, T. Concept of microsmoothing in electropolishing process. // Surface and Coatings Technology. 64, 2(1994), pp. 75-80.

[10] Hryniewicz, T.; Rokosz, K. Polarization Characteristics of Magnetoelectropolishing Stainless Steels. // Materials Chemistry and Physics. 122, (2010), pp. 169-174.

[11] Hryniewicz, T.; Rokicki, R.; Rokosz, K. Surface characterization of AISI 316L biomaterials obtained by electropolishing in a magnetic field. // Surface and Coatings Technology. 202, 9(2008), pp. 1668-1673.

[12] Hryniewicz, T.; Rokosz, K.; Rokicki, R. Electrochemical and XPS Studies of AISI 316L Stainless Steel after Electropolishing in a Magnetic Field. // Corrosion Sci. 50, 9(2008), pp. 2676-2681

[13] Hryniewicz, T.; Rokicki， R.; Rokosz， K. Corrosion Characteristics of Medical Grade AISI 316L Stainless Steel Surface after Electropolishing in a Magnetic Field. // CORROSION (The Journal of Science and Engineering), Corrosion Science Section. 64, 8(2008), pp. 660-665.

[14] Rokicki, R. US Patent No. 7632390 (2009). http://www.patentgenius.com/patent/7632390.html

[15] Product Data Bulletin, 316/316L Stainless Steel, AK Steel Corporation, PD-140 7180-0127 PDF 7/00, (2000). www.aksteel.com

[16] Hryniewicz, T.; Rokosz, K. Investigation of selected surface properties of AISI 316L SS after magnetoelectropolishing. // Materials Chemistry and Physics. 123, (2010), pp. 47-55. DOI: 10.1016/j.matchemphys.2010.03.060

[17] Hloch, S.; Kl'oc, J.; Hreha, P.; Magurová, D.; Kozak, D.; Knapčíková, L. Water jet technology using in orthopaedic surgery. // Tehnicki Vjesnik-Technical Gazette. 20, 2(2013), pp. 351-357.

[18] Rokosz, K.; Hryniewicz, T.; Raaen S. Characterization of Passive Film Formed on AISI 316L Stainless Steel after 
Magnetoelectropolishing in a Broad Range of Polarization Parameters.// Steel Research International. 83, 9(2012), pp. 910-918. DOI: 10.1002/srin.201200046

[19] ASTM A967 / A967M - 13 Standard Specification for Chemical Passivation Treatments for Stainless Steel Parts

[20] O'Laoire, C.; Timmins, B.; Kremer, L.; Holmes, J. D.; Morris, M. A. Analysis of the Acid Passivation of Stainless Steel.// Analytical Letters. 39, 11(2006), pp. 2255-2271. DOI: 10.1080/00032710600755363

[21] Noh, J. S.; Laycock, N. J.; Gao, W.; Wells, D. B. Effects of nitric acid passivation on the pitting resistance of 316 stainless steel. // Corrosion Sci. 42, 12(2000), pp. 20692084. DOI: $10.1016 / \mathrm{S} 0010-938 \mathrm{X}(00) 00052-4$

[22] Fairley, N. http://www.casaxps.com, C Casa software Ltd., (2005).

[23] Walton, J.; Carrick, A. The Casa Cookbook-The CasaXPS User's Manual, Part 1: Recipes for XPS data proceedings. ISBN: 9780954953300, Publisher: Acolyte Science, (2009).

[24] CasaXPS Processing Software, CasaXPS Manual 2.3.15 Rev 1.0, Copyright (C) 2010 Casa Software Ltd, pp. 19-20.

[25] Herrera-Gomez, A. The Peak-Shirley Background (Shirley background in overlapping peaks). Centro de Investigación y de Estudios Avanzados del IPN Unidad Querétaro, Internal Report Created 8/2011, Last Update 2/2012, (14 pages).

[26] Biesinger, M. C.; Payne, B. P.; Grosvenor, A. P.; Lau, L. W. M.; Gerson, A. R.; Smart, R. St.C. Resolving surface chemical states in XPS analysis of first row transition metals, oxides and hydroxides: $\mathrm{Cr}, \mathrm{Mn}, \mathrm{Fe}, \mathrm{Co}$ and $\mathrm{Ni}$. // Applied Surface Science. 257, (2011), pp. 2717-2730.

[27] Rokosz, K.; Hryniewicz, T.; Raaen S. XPS measurements of AISI 430 SS surface after electropolishing operations in a transpassive region of polarisation characteristics. // PAK (Measurement Automation and Monitoring). 58, 1(2012), pp. 126-129.

[28] Rokosz, K.; Hryniewicz, T. XPS measurements of passive film formed on AISI 3161 ss after electropolishing in a magnetic field (MEP). // Advances in Materials Science. 34(4) (2012), pp. 13-22. DOI: 10.2478/v10077-012-0012-5

[29] Rokosz, K.; Hryniewicz, T. Cr/Fe Ratio by XPS Spectra of Magnetoelectropolished AISI 316L SS Using Linear, Shirley and Tougaard Methods of Background Subtraction. // Advances in Materials Science. 13, 1(2013), pp. 11-20. DOI: 10.2478/adms-2013-0002

[30] Henkel, G.; Henkel, B. Die passivierung von austenitischen edelstahl- oberflachen in der pharmazeutischen industrie unter berücksichtigung von rougingphänomenen. // Technical Bulletin, HENKEL Beiz- und Elektropoliertechnik GmbH \& Co. KG, 2003, www.henkelepol.com

\section{Authors' addresses}

\section{Krzysztof Rokosz}

Division of Surface Electrochemistry and Technology Koszalin University of Technology

Racławicka 15-17,

75-620 Koszalin, Poland

E-mail: rokosz@tu.koszalin.pl

Tadeusz Hryniewicz (corresponding author)

Division of Surface Electrochemistry and Technology

Koszalin University of Technology

Racławicka 15-17,

75-620 Koszalin, Poland

E-mail: Tadeusz.Hryniewicz@tu.koszalin.pl

\section{Steinar Raaen}

Physics Department

NTNU, NO-7491 Trondheim, Norway

E-mail: sraaen@ntnu.no

\section{Jan Valiček}

Institute of Physics, Faculty of Mining and Geology, VŠB - Technical University of Ostrava, 17. listopadu $15 / 2172$

70833 Ostrava-Poruba, Czech Republic

E-mail: jan.valicek@vsb.cz 